\title{
Deviations in Peripheral Blood Cell Populations are Associated with the Stage of Primary Biliary Cholangitis and Presence of Itching
}

\author{
Halina Cichoż-Lach ${ }^{1}$ (D) Ewelina Grywalska ${ }^{2}$ - Agata Michalak ${ }^{1}$ (D) Agnieszka Kowalik AD $^{1} \cdot$ Michał Mielnik $^{2}$ (D) \\ Jacek Roliński ${ }^{2}$
}

Received: 4 March 2018 / Accepted: 29 May 2018 / Published online: 27 June 2018

(c) The Author(s) 2018

\begin{abstract}
To evaluate the role of Th17, Treg cells, activated T CD3 ${ }^{+}$and B CD19 ${ }^{+}$lymphocytes in primary biliary cholangitis (PBC) patients. 40 female patients with $\mathrm{PBC}$ and 20 healthy donors were enrolled in this study. The percentages and absolute counts

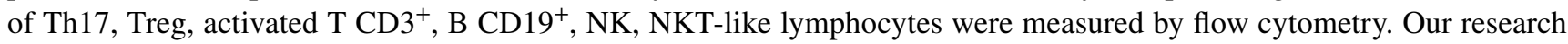
revealed significantly lower frequencies and absolute counts of $\mathrm{CD} 4^{+} \mathrm{CD} 25^{+} \mathrm{FOXP} 3^{+}$Treg cells $(p<0.0001)$, higher percentages and absolute counts of Th17 cells (IL-17A ${ }^{+} \mathrm{CD}^{+} \mathrm{CD}^{+} ; p<0.0001$ and $p=0.009$, respectively), $\mathrm{CD}^{-} / \mathrm{CD} 16^{+} \mathrm{CD} 56^{+}$ NK cells $\left(p<0.0001\right.$ and $p=0.039$, respectively), $\mathrm{CD}^{+} / \mathrm{CD} 16^{+} \mathrm{CD} 56^{+}$NKT-like cells $(p<0.0001$ and $p=0.048$, respectively). There were also higher percentages and numbers of B CD19 ${ }^{+}$lymphocytes $(p=0.002$ and $p=0.001$, respectively) and higher percentages and absolute counts of activated B CD19 ${ }^{+}$CD25 $5^{+}$cells $(p=0.007$ and $p=0.002$, respectively). Moreover, we observed a statistically significant correlation between the presence of itching and particular peripheral blood subpopulations in PBC patients. Absolute counts of both $\mathrm{CD} 4^{+} \mathrm{CD} 3^{+}$cells $(p=0.0119)$ and $\mathrm{CD} 3^{+} \mathrm{CD} 25^{+}$cells $(p=0.0329)$ were lower in patients with pruritus. A similar dependency was noted in reference to percentages of NKT-like cells $\left(\mathrm{CD} 3^{+} /\right.$ $\left.\mathrm{CD}_{16}{ }^{+} \mathrm{CD}_{56}{ }^{+} ; p=0.0359\right)$ and $\left(\mathrm{CD}^{+}\right) \mathrm{T}$ lymphocytes $(p=0.0302)$. Th17 and Treg cells are involved in the course of PBC. There is also the association between the pruritus and peripheral blood subpopulations.
\end{abstract}

Keywords Primary biliary cholangitis · Immune dysfunction · Pruritus

\section{Introduction}

Primary biliary cholangitis (PBC) is a chronic cholestatic liver disease characterized by progressive destruction of small size intrahepatic bile ducts leading to cholangitis. Among genetic and environmental factors, also the immunological background has conclusively been shown to contribute to the pathogenesis of PBC. Presence of serum antimitochondrial antibodies (AMA) constitutes the marker of PBC, noticed in 90-95\% of patients (Lindor et al. 2009). $\mathrm{PBC}$ is the most frequent autoimmune cholestatic liver disease in humans. Pathological appearance of PBC is inseparably connected with peripheral blood cell subpopulations,

Halina Cichoż-Lach

lach.halina@wp.pl

1 Department of Gastroenterology, Medical University of Lublin, Jaczewski 8, 20-954 Lublin, Poland

2 Department of Clinical Immunology and Immunotherapy, Medical University of Lublin, Lublin, Poland particularly T-regulatory- (Treg) and T-helper 17 (Th17) lymphocytes. Nevertheless, their role in PBC pathogenesis remains still uncertain. Scientists proved that manifestation of autoimmunity in humans is inseparably linked to the quantitative and qualitative irregularities of Treg lymphocytes (Chen et al. 2012; Du et al. 2013; Furuhashi et al. 2013; Klatka et al. 2014). It has been shown that activated Treg lymphocytes can inhibit the immunological response irrespective of the antigen (van Herwijnen et al. 2012). Moreover, Th17 lymphocytes are also directly involved in the course of various autoimmune diseases; nevertheless a certain mechanism of their action differs (Murdaca et al. 2011; Pesce et al. 2013; Singh et al. 2013; Vargas-Lowy et al. 2012)..The aim of this research was to describe the percentages and absolute counts of Th17, Treg, as well as activated $\mathrm{T} \mathrm{CD}^{+}$and $\mathrm{B} \mathrm{CD} 19^{+}$lymphocytes in patients with newly diagnosed $\mathrm{PBC}$ and to assess the relationships between analyzed cell subsets and selected clinical parameters (presence of itching and the degree of PBC severity). 


\section{Materials and Methods}

\section{Ethics Statement}

The research protocol was approved by the Ethics Committee at the Medical University of Lublin (No. 131/2013) and all patients gave their written informed consent.

\section{Patients and Controls}

Peripheral blood was obtained from 40 previously untreated female patients with $\mathrm{PBC}$ (mean age 52.4 \pm 12.5 ; range 37-68 years), and from 20 sex-matched healthy donors (mean age $49.8 \pm 6.7$; range $36-71$ years). The diagnosis of PBC was based on typical diagnostic criteria: (1) biochemical evidence of cholestasis based mainly on elevated alkaline phosphatase activity, (2) presence of AMA and (3) histologic evidence of nonsuppurative destructive cholangitis and destruction of interlobular bile ducts in liver biopsy. All examined patients fulfill all three diagnostic criteria. The degree of severity of PBC was evaluated by histologic stages of PBC. This parameter was described in all patients and they were divided into four groups, according to histologic stages of PBC (I, portal stage - 7 patients; II, periportal stage-16 patients; III, septal stage-11 patients; IV, cirrhotic stage -6 patients). Before the initiation of treatment of PBC, lymphocyte subsets, values of peripheral blood cell count parameters, and immunoglobulin serum levels were measured. Itching of the skin was observed in 18 patients. The severity of pruritus was assessed according to visual analog scale (VAS) questionnaire and the mean result was $4.1 / 10$ points. Baseline characteristics of the patients are shown in Table 1. None of the patients and controls had signs of infection at the time of investigation and for a month before collection of the samples and none had been taking drugs with known influence on the immune system, including oral contraceptives. None of the patients or healthy participants had undergone a blood transfusion. Persons with a history of allergic diseases, as well as other autoimmune diseases, were excluded from the study.

\section{Blood Sampling}

Venous blood samples (peripheral blood) were collected from the studied patients and controls by venipuncture using sterile, lithium heparin-treated tubes (S-Monovette, SARSTEDT, Aktiengesellschaft \& Co., Nubrecht, Germany).

\section{Isolation of Peripheral Bood Cells and the Detection of Th17 and Treg Cells}

Peripheral blood mononuclear cells (PBMCs) were aseptically separated by a standard density gradient centrifugation (Gradisol L, Aqua Medica, Poland).
Table 1 The demographic characteristics and results of laboratory tests in examined patients

\begin{tabular}{llll}
\hline Parameter & PBC patients $(n=40)$ & Controls $(n=20)$ & $p$ value \\
\hline Stage of disease & I, 7 pts; II, 16 pts; III, 11 pts; & & \\
& IV, 6 pts & & \\
Presence of pruritus & $n=18$ & & \\
AMA positivity $(\geq 1: 40)$ & $n=40$ & $49.8 \pm 6.7$ & NS \\
Age (years) & $52.4 \pm 12.5$ & $20 / 0$ & $\mathrm{NS}$ \\
Gender F/M & $34 / 0$ & $98.1 \pm 27.2$ & $0.0015^{*}$ \\
ALP activity [U/l] & $254.2 \pm 98.2$ & $39.67 \pm 16.5$ & $0.0001^{*}$ \\
GGT activity [U/l] & $245.2 \pm 125.8$ & $24.0 \pm 11.7$ & $0.0325^{*}$ \\
ALT [U/l] & $67.3 \pm 28.5$ & $21.8 \pm 8.2$ & $\mathrm{NS}$ \\
AST [U/l] & $43.1 \pm 17.4$ & $12.1 \pm 2.3$ & $\mathrm{NS}$ \\
Prothrombin time [s] & $12.8 \pm 1.3$ & $0.8 \pm 0.4$ & $0.0032^{*}$ \\
Bilirubin [mg/dl] & $3.4 \pm 1.8$ & $327.3 \pm 127.5$ & $\mathrm{NS}$ \\
IgM [IU/ml] & $317.9 \pm 115.2$ & $1543 \pm 247.9$ & $\mathrm{NS}$ \\
IgG [IU/ml] & $1345.3 \pm 234.7$ & $3.9 \pm 1.0$ & $\mathrm{NS}$ \\
Albumin [g/dl] & $3.6 \pm 1.3$ & $234.8 \pm 98.4$ & $\mathrm{NS}$ \\
PTC [109/l] & $197.4 \pm 67.3$ & &
\end{tabular}

Age and results of laboratory tests are presented as mean \pm SD (standard deviation)

$N S$ not significant, $n$ number of patients, $p t s$ patients, $A M A$ antimitochondrial antibodies, $F$ females, $M$ males, $A L S$ alcoholic liver steatosis, $A L T$ alanine aminotransferase, ASH alcoholic steatohepatitis, AST aspartate transaminase, $A L P$ alkaline phosphatase, GGT gamma-glutamyl transferase, IgM immunoglobulin $\mathrm{M}, I g G$ immunoglobulin $\mathrm{G}, P T C$ platelet count

*Statistically significant differences vs. controls, $p<0.05$ 
Tregs in the peripheral blood were assessed by analyzing the expression of the CD4 and CD25 cell surface antigens, as well as the expression of the intracellular FOXP3 antigen using a BD FACSCalibur flow cytometer (BD Biosciences, USA). The percentage of $\mathrm{CD} 4{ }^{+} \mathrm{CD} 25^{+} \mathrm{FOXP} 3^{+}$Tregs in the $\mathrm{CD} 4^{+} \mathrm{T}$ lymphocyte subpopulation was determined using the Human Treg Flow kit (FOXP3 Alexa Fluor 488/CD4 PE-Cy5/CD25 PE, BioLegend, USA) according to the manufacturer's instructions (Fig. 1).

For the detection of Th17 cells, PBMCs were resuspended in RPMI-1640 culture medium (SigmaAldrich, USA) containing 5\% human albumin (Baxter, USA), $2 \mathrm{mM}$ L-glutamine, $100 \mathrm{U} / \mathrm{ml}$ penicillin (Sigma,
Germany), and $100 \mu \mathrm{g} / \mathrm{ml}$ streptomycin (Sigma-Aldrich, USA). We stimulated mononuclear cells for $5 \mathrm{~h}$ at $37^{\circ} \mathrm{C}$ in $5 \% \mathrm{CO}_{2}$ with $25 \mathrm{ng} / \mathrm{ml}$ of phorbol 12 -myristate 13 -acetate- PMA, (Sigma Aldrich, USA) and $1 \mu \mathrm{g} / \mathrm{ml}$ of ionomycin (Sigma-Aldrich, USA) in the presence of $1 \mu \mathrm{g} / \mathrm{ml}$ of Brefeldin A (Sigma-Aldrich, USA), which blocks the intracellular transport processes resulting in the accumulation of cytokine proteins on the Golgi complex. Next, PBMCs were collected, washed with PBS without $\mathrm{Ca}^{2+}$ and $\mathrm{Mg}^{2+}$ solution and prepared at a final concentration of $10^{6}$ cells $/ 100 \mu \mathrm{l}$ per tube. Then, the cells were stained with anti-CD3 PE-Cy5 and anti-CD4 fluorescein-isothiocyanate (FITC)-conjugated monoclonal antibodies (Becton
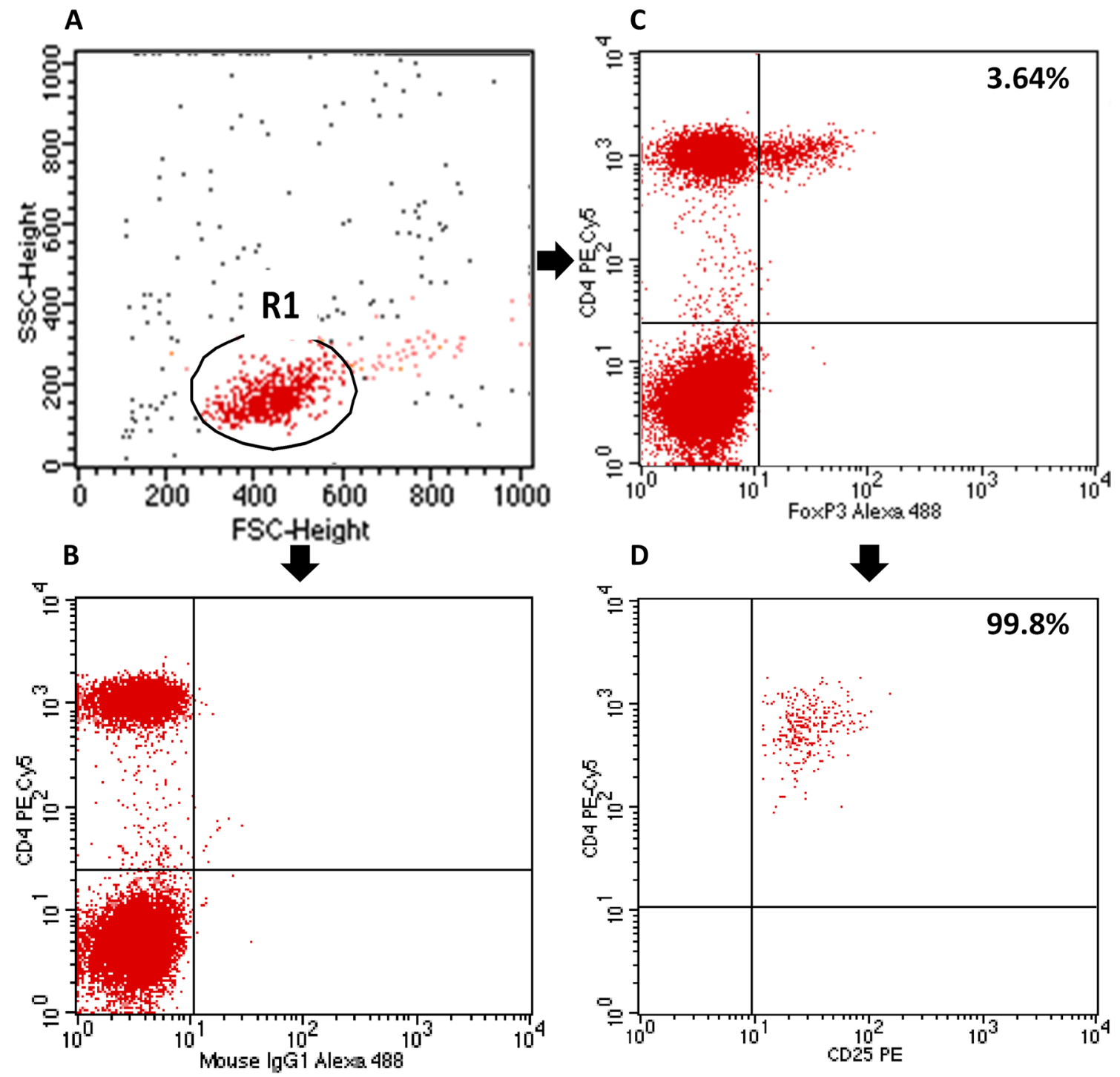

Fig. 1 Flow cytometric analysis of T regulatory cells (Treg). First, lymphocytes were gated (R1) on the basis of FSC (forward scatter channel) vs. SSC (side scatter channel) signals. CD4 ${ }^{+}$lymphocytes were then gated and the proportion of $\mathrm{CD} 25^{+} \mathrm{FOXP} 3^{+}$cells among

the $\mathrm{CD}^{+}$cells was estimated. a Lymphocyte gating. b Isotype control. c Sample analysis of $\mathrm{FOXP}^{+}$in $\mathrm{CD}^{+}$cells (Treg- $3.64 \%$ ). d $99.8 \%$ of $\mathrm{CD}^{+}{ }^{+} \mathrm{FOXP}^{+}$cells co-express $\mathrm{CD} 25$ antigen 
Dickinson, USA). Following the surface staining, cells were fixed and permeabilized using Cytofix/Cytoperm Fixation/Permeabilization Kit (BD Biosciences, USA) according to the manufacturer's instructions. The permeabilized cells were stained with PE-conjugated anti-human IL-17A monoclonal antibody (MACS Miltenyi Biotec, Germany) or a PE IgG1 isotype control (Fig. 2). Finally, cells were washed and analyzed by flow cytometry, performed on a BD FACSCalibur System (BD Biosciences, USA) (Darmochwał-Kolarz et al. 2012; Hus et al. 2013, 2017; Klatka et al. 2014).
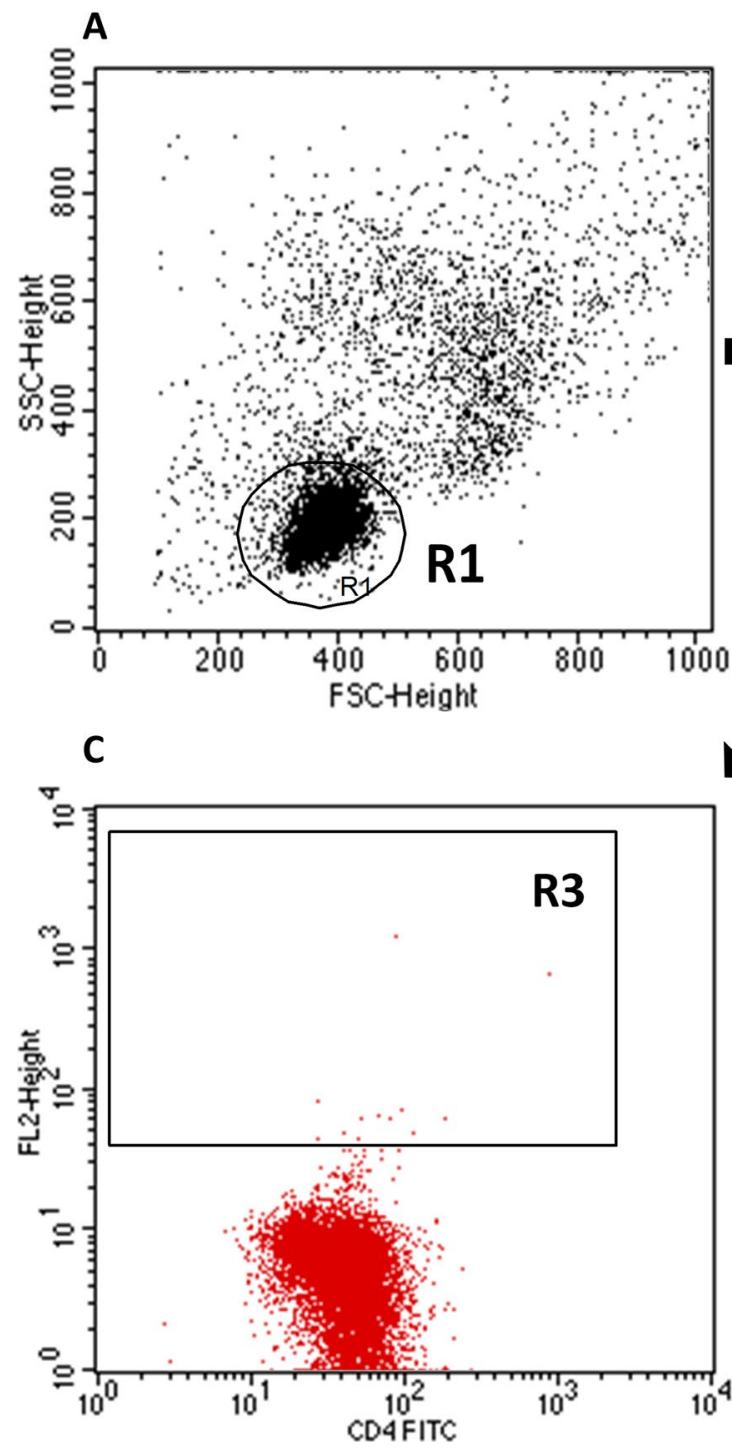

Fig. 2 Representative flow cytometric analysis of Th17 cells. First, lymphocytes were gated (R1) on the basis of FSC (forward scatter channel) vs. SSC (side scatter channel) signals. The second step was gating (R2) of $\mathrm{CD}^{+}$lymphocytes and subsequently estimation of

\section{Immunophenotyping of Natural Killer and Natural Killer T-Like Cells as well as T CD3 ${ }^{+}$and B CD19 ${ }^{+}$ Lymphocytes}

Percentages of natural killer (NK) and natural killer T-like (NKT-like) cells were evaluated with flow cytometry using monoclonal antibody anti-CD3 FITC/CD $16^{+} \mathrm{CD} 56$ PE (BD Biosciences, USA), which allowed for simultaneous assessment of $\mathrm{T} \mathrm{CD}^{+}$lymphocytes and NK cells $\mathrm{CD}^{-} / \mathrm{CD} 16^{+} \mathrm{CD}^{+} 6^{+}$. During analysis, the NKT-like $\mathrm{CD}^{+} /$ $\mathrm{CD} 16^{+} \mathrm{CD} 56^{+}$population was also determined (Fig. 3). A standard, whole-blood assay with erythrocyte cell lysis was used to prepare the peripheral blood samples. Immunofluorescence studies on $\mathrm{T} \mathrm{CD}^{+}$and $\mathrm{B} \mathrm{CD} 19^{+}$cell subsets were
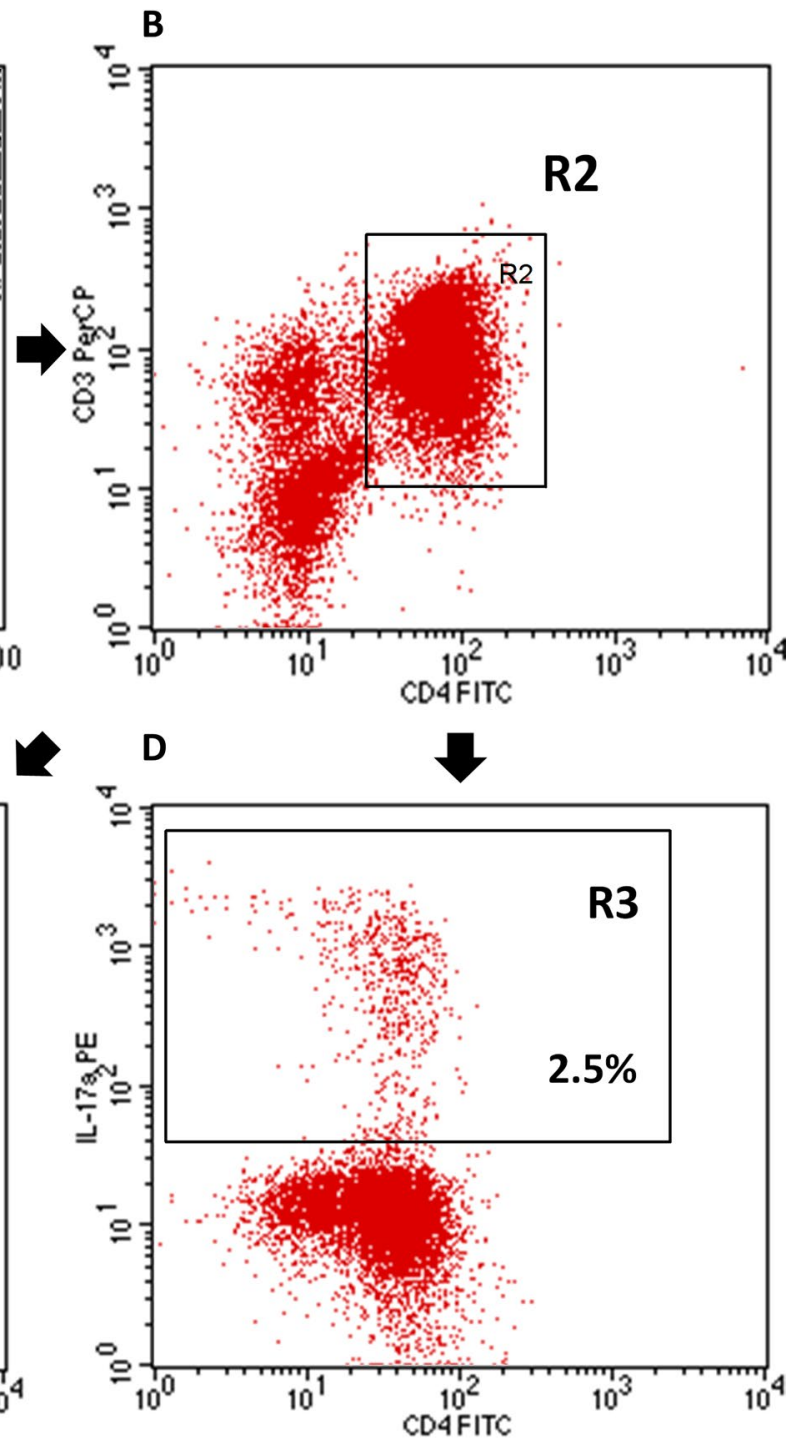

IL-17 $\mathrm{A}^{+}$cells among $\mathrm{CD} 4^{+}$cells. a Lymphocyte gating. b Gating of $\mathrm{CD}^{+} \mathrm{CD}^{+}$lymphocytes. $\mathbf{c}$ Isotype control. d Sample analysis of IL$17 \mathrm{~A}^{+}$in $\mathrm{CD}^{+} \mathrm{CD}^{+}$cells $(\mathrm{R} 3-2.5 \%)$ 

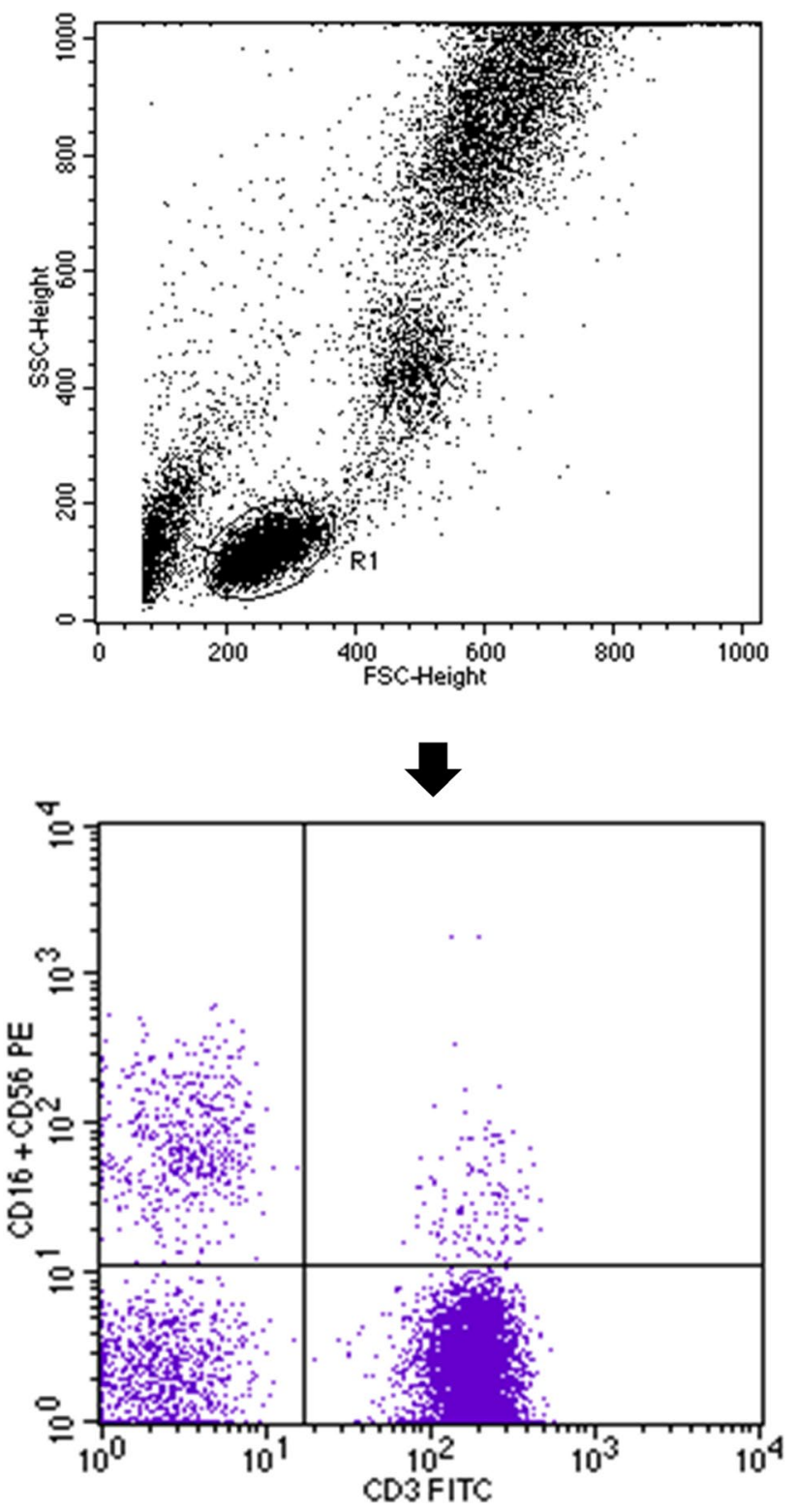

Fig. 3 Flow cytometric analysis of NK- and NKT-like cells. First, lymphocytes were gated (R1) on the basis of FSC (forward scatter channel) vs. SSC (side scatter channel) signals (upper dot plot). Finally, dot plot $\mathrm{CD}^{+}$FITC vs. $\mathrm{CD}^{+} 6^{+} \mathrm{CD} 56^{+} \mathrm{PE}$ was established. The upper left quadrant of the bottom dot plot represents the percentage of $\mathrm{CD}^{-} / \mathrm{CD} 16^{+} \mathrm{CD}^{2} 6^{+}(\mathrm{NK})$ cells and the upper right quadrant of the bottom dot plot represents the percentage of $\mathrm{CD}^{+} /$ $\mathrm{CD} 6^{+} \mathrm{CD}^{2} 6^{+} \mathrm{T}$ (NKT-like) cells

performed using a combination of the following monoclonal antibodies: anti-CD3 FITC/CD19 PE and anti-CD4 FITC/CD8 PE/CD3 PE-Cy5 (BD Biosciences, USA). To determine the activated peripheral blood cells, we used the anti-CD25 PE-Cy5 mouse monoclonal antibody (BD Biosciences, USA). "Cleanness" of lymphocyte gateway was evaluated by examining the distribution of cells in the coordinates of CD45/CD14 (BD Biosciences, USA). The percentage of positive cells was measured from a cut-off set using isotype-matched nonspecific control antibody. Threecolour immunofluorescence analyses were performed using a FACSCalibur flow cytometer (BD Biosciences, USA) equipped with $488 \mathrm{~nm}$ argon laser. A minimum of 10,000 events was acquired and analyzed using CellQuest Software (BD Biosciences, USA). The percentage of cells expressing surface markers were analyzed (Hus et al. 2011; Klatka et al. 2017; Nowicka et al. 2017; Pasiarski et al. 2015).

\section{Statistical Analysis}

Statistical analysis of the results was conducted using Statistica 9.0. The demographic date and results of laboratory tests were presented as the mean value \pm SD and Student's $t$ test was used to compare these results. Deviation from normality was evaluated by Kolmogorov-Smirnov test. Data were expressed as the median and range (minimum-maximum). The Mann-Whitney $U$ test and Kruskal-Wallis test were used for between-group comparisons because of nonnormal distribution. Spearman correlation analyses were used to verify the correlation. All probability values were two-tailed, and a value of $p$ less than 0.05 was considered statistically significant.

\section{Results}

The demographic characteristics and results of laboratory tests in examined patients and controls are presented in the Table 1.

\section{Differences in Tested Parameters between the Study and Control Groups}

Our investigation revealed noteworthy differences in the tested parameters between the study and control groups (Table 2). Significantly lower frequencies and absolute counts of $\mathrm{CD}^{+}{ }^{+} \mathrm{CD} 25^{+} \mathrm{FOXP} 3{ }^{+}$Treg cells were found in the study group in comparison to healthy controls (in both cases $p<0.0001)$. Higher percentages and absolute counts of IL-17 $\mathrm{A}^{+} \mathrm{CD}^{+} \mathrm{CD}^{+} \mathrm{Th} 17$ lymphocytes were found in the peripheral blood of $\mathrm{PBC}$ patients than in the control group ( $p<0.0001$ and $p=0.009$, respectively). Statistically higher percentages and absolute counts of $\mathrm{CD}^{-} / \mathrm{CD}^{-} 6^{+} \mathrm{CD}^{-} 6^{+} \mathrm{NK}$ cells were found in the study group than in the control group ( $p<0.0001$ and $p=0.039$, respectively). The frequencies and absolute counts of $\mathrm{CD}^{+} / \mathrm{CD} 16^{+} \mathrm{CD} 56^{+} \mathrm{NKT}$-like cells were also significantly higher in $\mathrm{PBC}$ patients than in healthy donors $(p<0.0001$ and $p=0.048$, respectively). There were no significant differences between the frequencies and absolute counts of $\mathrm{T} \mathrm{CD}^{+}$cells among analyzed groups (in both cases $p>0.1$ ). However, higher percentages as well 
Table 2 Differences in the tested parameters between the study and control groups

\begin{tabular}{|c|c|c|c|c|c|c|}
\hline \multirow[t]{2}{*}{ Parameter } & \multicolumn{2}{|c|}{ PBC patients $(n=40)$} & \multicolumn{2}{|c|}{ Controls $(n=20)$} & \multirow[t]{2}{*}{$Z$} & \multirow[t]{2}{*}{$p$ value } \\
\hline & $\mathrm{Me}$ & Range, min-max & $\mathrm{Me}$ & Range, min-max & & \\
\hline Lymphocytes $\left[\times 10^{3} / \mathrm{ul}\right]$ & 1.51 & $0.14-13.40$ & 2.15 & $1.26-3.12$ & -2.723 & $0.006^{* *}$ \\
\hline $\mathrm{CD}^{+} \mathrm{CD} 25^{+} \mathrm{FOXP} 3^{+}$Treg cells [\%] & 3.79 & $0.65-7.20$ & 7.91 & $5.42-11.26$ & -5.660 & $0.000 * * *$ \\
\hline $\mathrm{CD}^{+}{ }^{+} \mathrm{CD} 25^{+} \mathrm{FOXP}^{+}$Treg cells $\left[\times 10^{3} / \mathrm{ul}\right]$ & 0.06 & $0.00-0.16$ & 0.18 & $0.07-0.33$ & -5.123 & $0.000 * * *$ \\
\hline IL-17A ${ }^{+} \mathrm{CD}^{+}{ }^{+} \mathrm{CD} 4^{+}$Th17 lymphocytes [\%] & 13.53 & $3.54-32.75$ & 5.16 & $0.34-15.65$ & 4.550 & $0.000 * * *$ \\
\hline IL-17A ${ }^{+} \mathrm{CD}^{+}{ }^{+} \mathrm{CD}^{+}{ }^{+} \mathrm{Th} 17$ lymphocytes $\left[\times 10^{3} / \mathrm{ul}\right]$ & 0.24 & $0.03-1.56$ & 0.12 & $0.00-0.46$ & 2.615 & $0.009 * *$ \\
\hline $\mathrm{CD}^{-} / \mathrm{CD} 16^{+} \mathrm{CD}^{2} 6^{+} \mathrm{NK}$ cells $[\%]$ & 22.37 & $10.25-37.50$ & 12.40 & $5.06-17.18$ & 4.792 & $0.000 * * *$ \\
\hline $\mathrm{CD}^{-} / \mathrm{CD} 16^{+} \mathrm{CD} 6^{+} \mathrm{NK}$ cells $\left[10^{3} / \mathrm{mm}^{3}\right]$ & 0.34 & $0.02-2.88$ & 0.26 & $0.11-0.54$ & 2.060 & $0.039^{*}$ \\
\hline $\mathrm{CD}^{+} / \mathrm{CD} 16^{+} \mathrm{CD}^{2} 6^{+}$NKT-like cells [\%] & 5.75 & $2.74-10.94$ & 2.79 & $1.11-4.27$ & 4.792 & $0.000 * * *$ \\
\hline $\mathrm{CD}^{+} / \mathrm{CD} 16^{+} \mathrm{CD} 6^{+} \mathrm{NKT}$-like cells $\left[10^{3} / \mathrm{mm}^{3}\right]$ & 0.09 & $0.01-0.74$ & 0.07 & $0.02-0.13$ & 1.899 & $0.048^{*}$ \\
\hline T lymphocytes $\mathrm{CD}^{+}[\%]$ & 65.69 & $45.48-78.78$ & 68.55 & $13.21-78.63$ & -0.909 & $0.363^{\mathrm{NS}}$ \\
\hline T lymphocytes $\mathrm{CD}^{+}\left[10^{3} / \mathrm{mm}^{3}\right]$ & 1.66 & $0.67-3.92$ & 1.65 & $0.35-2.49$ & 0.556 & $0.578^{\mathrm{NS}}$ \\
\hline $\mathrm{CD}^{+} \mathrm{CD} 25^{+}[\%]$ & 11.67 & $1.60-28.13$ & 7.54 & $1.08-10.85$ & 3.088 & $0.002 * *$ \\
\hline $\mathrm{CD}^{+} \mathrm{CD}^{2} 5^{+}\left[10^{3} / \mathrm{mm}^{3}\right]$ & 0.28 & $0.04-0.91$ & 0.16 & $0.03-0.38$ & 3.190 & $0.001 * *$ \\
\hline B lymphocytes CD19+ [\%] & 11.73 & $7.16-24.53$ & 8.77 & $5.48-47.40$ & 3.153 & $0.002 * *$ \\
\hline B lymphocytes CD $19^{+}\left[10^{3} / \mathrm{mm}^{3}\right]$ & 0.33 & $0.16-0.94$ & 0.20 & $0.13-1.26$ & 3.357 & $0.001 * * *$ \\
\hline $\mathrm{CD}^{+} \mathrm{CD}^{+}[\%]$ & 38.93 & $15.79-49.82$ & 45.0 & $34.71-48.88$ & -3.348 & $0.0008 * * *$ \\
\hline $\mathrm{CD}^{+} \mathrm{CD}^{+}\left[10^{3} / \mathrm{mm}^{3}\right]$ & 0.91 & $0.31-2.43$ & 1.08 & $0.57-1.65$ & -1.280 & $0.20006^{\mathrm{NS}}$ \\
\hline $\mathrm{CD} 19^{+} \mathrm{CD} 25^{+}[\%]$ & 3.27 & $0.48-13.06$ & 1.81 & $0.06-5.12$ & 2.693 & $0.007 * *$ \\
\hline $\mathrm{CD} 19^{+} \mathrm{CD} 25^{+}\left[10^{3} / \mathrm{mm}^{3}\right]$ & 0.08 & $0.02-0.39$ & 0.04 & $0.00-0.14$ & 3.135 & $0.002 * *$ \\
\hline
\end{tabular}

$N S$ not significant, $M e$ median

${ }^{*} p<0.05 ;{ }^{* *} p<0.01 ;{ }^{* * *} p<0.001$

as numbers of activated $\mathrm{T} \mathrm{CD} 3{ }^{+} \mathrm{CD} 25^{+}$lymphocytes were found in PBC patients comparing to controls ( $p=0.002$ and $p=0.001$, respectively). Our research revealed also that in the study group there were higher percentages and numbers of B CD $19^{+}$lymphocytes $(p=0.002$ and $p=0.001$, respectively), as well as higher percentages and absolute counts of activated B CD $19^{+} \mathrm{CD} 25^{+}$cells $(p=0.007$ and $p=0.002$, respectively).

\section{The Relationships Between the Tested Parameters and Stages of PBC and Presence of Itching}

Our study revealed that the course of PBC might be affected by certain peripheral blood cell subpopulations (Table 3 ). Current survey demonstrated the correlation between the histologic stage of PBC (II and III) and absolute counts of several peripheral blood subpopulations: $\mathrm{CD} 4^{+} \mathrm{CD} 25^{+} \mathrm{FOXP} 3^{+}$ Treg cells, $\left(\mathrm{CD}^{+} / \mathrm{CD} 16^{+} \mathrm{CD}^{2} 6^{+}\right)$NKT-like cells, $\mathrm{CD} 3^{+} \mathrm{T}$ lymphocytes and $\mathrm{CD}^{+}{ }^{+} \mathrm{CD} 3^{+}$cells. A statistically significant higher concentration of Treg cells and NKT-like cells was observed in the III stage PBC patients in comparison to the II stage. Furthermore, a statistically significant lower concentration of $\mathrm{CD}^{+} \mathrm{T}$ lymphocytes and $\mathrm{CD} 4{ }^{+} \mathrm{CD}^{+}$cells was noted in the III stage PBC patients in comparison to the II stage. Additionally, we observed a statistically significant correlation between percentages and absolute counts of $\mathrm{CD}^{+} \mathrm{CD}^{2} 5^{+}$cells in the I and the II histologic stage of PBC; their concentration was higher in the II stage in comparison to the I stage. Only six patients of the research group showed the IV stage of PBC, thus too small number of subjects in this group may explain the lack of statistically significant differences between remained biopsied groups. Interestingly, our investigation found out that there is a statistically significant correlation between the presence of itching and particular peripheral blood subpopulations in $\mathrm{PBC}$ patients (Table 4). Absolute counts of both $\mathrm{CD} 3{ }^{+} \mathrm{CD} 4^{+}$cells $(p=0.0119)$ and $\mathrm{CD}^{+} \mathrm{CD} 25^{+}$cells $(p=0.0329)$ were lower in patients with itching. Furthermore, a similar dependency was noted in reference to percentages of NKT-like cells $\left(\mathrm{CD}^{+} / \mathrm{CD} 16^{+} \mathrm{CD}^{+} 6^{+} ; p=0.0359\right)$ and $\left(\mathrm{CD}^{+}\right) \mathrm{T}$ lymphocytes $(p=0.0302)$. The remaining examined parameters did not show statistical dependence with the presence of pruritus.

\section{Discussion}

Understanding a direct link between $\mathrm{T}$-cell reactivity and autoimmunity in the course of $\mathrm{PBC}$ was a great progress in the area of hepatology. PBC-like pathology reflected by inflammatory biliary ductulitis and the presence of AMA in serum was presented to accompany $\mathrm{T}$ cell abnormalities 


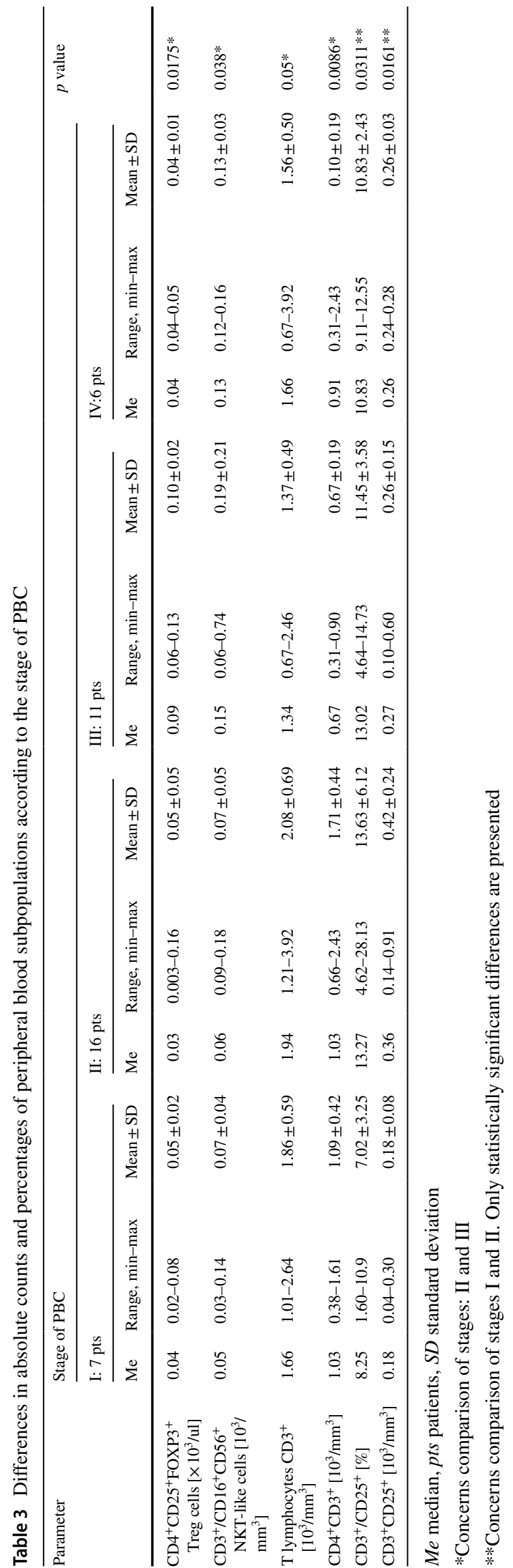

in genetically based mouse models (Mackay 2007). Our study supports this idea since we found the Treg deficiency as well as elevated $\mathrm{CD} 25^{+}$cells in the peripheral blood of PBC patients in comparison to healthy controls. Treg cells play a pivotal role in self-tolerance and controlling excessive immune responses. Their reduced number in PBC is a well-known phenomenon. It could be responsible for the loss of immune tolerance and development of autoimmune process. According to the previous studies, aberrations of $\mathrm{CD}^{+}$cells in $\mathrm{PBC}$ patients were also observed. Furthermore, B-cell-activating factor (BAFF) is involved in disorders in PBC affecting Treg cells. It is a crucial survival factor in the course of B-cell maturation. The level of BAFF in patients with diagnosed $\mathrm{PBC}$ is elevated. It has been confirmed that activated B cells are able to inhibit Treg cell proliferation. Interestingly, BAFF receptors on Treg cells have not been found. Investigations performed on PBC patients revealed that BAFF is responsible for the Treg cell apoptosis and inhibited cytokine production by activating B cells. These data are especially noteworthy because they suggest the inhibition of BAFF activation as a potential treatment strategy for PBC. What is more, mice with T-cell-restricted expression of a dominant negative form of the transforming growth factor (TGF)- $\beta$ receptor type II were observed to develop spontaneously autoimmune cholangitis resembling human $\mathrm{PBC}$, with the presence of AMA together with portal lymphocytic infiltration $\left(\mathrm{CD}^{+}, \mathrm{CD}^{+}\right)$. By means of this fact, the deprivation of TGF- $\beta$ signaling restricted to $T$ cells might be the reason of pathological appearance of PBC (Bernuzzi et al. 2010; Fenoglio et al. 2012; Huang et al. 2014; Wang et al. 2015; Zhang et al. 2013; Yang et al. 2008). Lan et al. (2009) detected elevated number of interleukin (IL)-17 producing cells in liver tissues of PBC patients in comparison to healthy controls. Those authors reported also the presence of $\mathrm{IL}-17^{+}$cells in livers of IL-2-knockout mice (since IL-2 inhibits Th17 cells production) (Lan et al. 2009). Herein, we report that higher levels of Th17 cells are found in the peripheral blood of $\mathrm{PBC}$ patients in comparison to healthy controls. Obtained results suggest also that severe immune system deregulation, reflected by high numbers of Th17 cells with additional low frequencies of Treg lymphocytes, may influence the severity of inflammatory response and the progression of disease to such an extent that these parameters correlate with histological stage of PBC. Th17 cells are a key factor in the pathogenesis and the development of many autoimmune disorders, e.g., autoimmune encephalitis, rheumatoid arthritis and inflammatory bowel disease (Brand 2009; Hamburg et al. 2011; Hot and Miossec 2011; Jadidi-Niaragh and Mirshafiey 2011; Noubade et al. 2011). The subpopulation of Th17 cells in the course of PBC is of crucial importance because of IL-17 production. This cytokine was proved to participate in tissue destruction and proinflammatory mediator induction. It 
Table 4 Differences in absolute counts and percentages of peripheral blood subpopulations with reference to the presence of pruritus

\begin{tabular}{|c|c|c|c|c|c|}
\hline \multirow[t]{3}{*}{ Parameter } & \multicolumn{4}{|c|}{ PBC patients $(n=40)$} & \multirow[t]{3}{*}{$p$ value } \\
\hline & \multicolumn{2}{|c|}{ Pruritus $(n=18)$} & \multicolumn{2}{|c|}{ No pruritus $(n=22)$} & \\
\hline & $\mathrm{Me}$ & Range, min-max & $\mathrm{Me}$ & Range, min-max & \\
\hline $\begin{array}{l}\mathrm{CD}^{+} / \mathrm{CD} 16^{+} \mathrm{CD} 6^{+} \mathrm{NKT}^{-} \\
\text {like cells }[\%]\end{array}$ & 4.35 & $2.74-10.94$ & 6.35 & $3.74-9.62$ & 0.0359 \\
\hline T lymphocytes CD3 ${ }^{+}[\%]$ & 62.62 & $52.74-73.94$ & 70.07 & $45.48-78.78$ & 0.0302 \\
\hline $\mathrm{CD}^{+}{ }^{+} \mathrm{CD}^{+}\left[10^{3} / \mathrm{mm}^{3}\right]$ & 0.86 & $0.31-1.61$ & 1.03 & $0.38-2.43$ & 0.0119 \\
\hline $\mathrm{CD}^{+} \mathrm{CD}^{2} 5^{+}\left[10^{3} / \mathrm{mm}^{3}\right]$ & 0.25 & $0.04-0.60$ & 0.31 & $0.14-0.91$ & 0.0329 \\
\hline
\end{tabular}

Only statistically significant differences are presented

Me median, $n$ number of patients is also responsible for the progression of fibrosis in various conditions, like myocardial fibrosis or bleomycin-induced idiopathic pulmonary fibrosis (Feng et al. 2009; Gasse et al. 2011; Wilson et al. 2010). The research conducted on IL17A-knockout mice with the model of PBC, revealed the reduction of AMA. Scientists showed also that the depletion of Th17 cell cytokines (IL-17A, IL-22) lowers the degree of biliary damage (Kawata et al. 2013). Moreover, IL-17 has a profibrotic profile and is implicated in organ fibrosis. Of note, biliary epithelial cells are able to release Th17-inducible cytokines. Other researchers found Th17 cells to accumulate in the area of damaged bile ducts in PBC patients. The loss of intrahepatic biliary ducts in PBC might be the result of epithelial to mesenchymal transition (EMT). This process stands for the phenotypic reprogram, which results in the loss of epithelial character and acquisition of feature close to fibroblasts. EMT was also shown to be a very early process in the course of PBC. Aforementioned profibrotic characteristics of IL-17 might be responsible for the liver fibrosis in the course of PBC. It may be also a potential target as a management for autoimmune liver diseases (Harada et al. 2009; Huang et al. 2016; Romagnani et al. 2009; Rong et al. 2009; Shi et al. 2015). Subsequently, EMT was also proved to attenuate fibrosis in various pathological states. Investigations revealed that IL-17 is able to activate EMT of alveolar and bronchial epithelial cells. The importance of IL-17 in disease progression requires further investigation, such as studies involving the blocking of IL-17 signals. The exact mechanism of the exuberant Th17 induction in PBC is not clear (Ji et al. 2013; Mi et al. 2011; Vittal et al. 2013). The dysregulation of NK cell induction seems to be another important underlying defect. Data in literature concerning the role of NK cells in the course of cholangitis are scanty and this area should be undoubtedly explored. Our investigation revealed increased frequency of both $\mathrm{CD}^{-} / \mathrm{CD} 16^{+} \mathrm{CD} 56^{+} \mathrm{NK}$ cells and $\mathrm{CD} 3^{+} / \mathrm{CD} 16^{+} \mathrm{CD} 56^{+}$ NKT-like cells in patients with PBC. The destruction of biliary cells in $\mathrm{PBC}$ is reported to consist of three main elements: macrophages, biliary epithelial apotopes and AMA. A final cascade leads to the release of proinflammatory cytokines. Furthermore, NK cell cytotoxicity is also widely emphasized because of their ability to synthesize cytokines rapidly. In consequence, they have an impact on quality and quantity of acquired immune responses. Scientists studied a murine model of human $\mathrm{PBC}$ with the depletion of NK and NK T cells and observed the suppression of AMA and cytokine release by autoreactive $\mathrm{T}$ cells. Interestingly, no statistically important change of portal inflammation was noted (Feuerer et al. 2009; Lanier 2008; Shimoda et al. 2012). According to conducted investigations, NK cells were reported to participate in the destruction of cholangiocytes. Moreover, NK T cells were found to be involved in the exacerbation of PBC (Chuang et al. 2008; Kita et al. 2002; Wu et al. 2011). By means of these data, it becomes quite obvious that innate immune effector mechanisms are inseparably connected with acquired immunity and play a crucial role in the pathogenesis of PBC. Nevertheless, the underlying mechanisms between innate immune effector actions and the development of pathogenically acquired immune responses in $\mathrm{PBC}$ remain unknown and still require further research (Berg 2011; Selmi et al. 2009). The limitation of current investigation is relatively a small number of participants. The further study should include the level of IL-17 as one of assessed the parameters in PBC patients. Furthermore, our investigation seems to be the first that demonstrated the correlation between pruritus and concentrations of certain peripheral blood subpopulations in PBC patients. This area should be undoubtedly explored in the future. Results achieved in this survey correlate with data in the literature and suggest immunological background as the key factor leading to PBC and one of the possible targets of treatment.

In conclusion, presented study demonstrates that both Th17 and Treg cells might play an important role in the pathogenesis and treatment of PBC. Reduced number of Treg cells and high level of Th17 cells in PBC could be responsible for the loss of immune tolerance, development of inflammatory, autoimmune process and liver fibrosis in PBC. The progression of the disease might be the result of Th17 cell activation and the release of IL-17. Treg cells and NKT-like cells correlate with histological stages of PBC. 
There is also the association between the presence of itching and concentrations of particular peripheral blood subpopulations. Undoubtedly, our results lay a solid base for further studies that we would like to continue in the near future. To our knowledge, this investigation is the first one performed in Polish population that assesses the correlation between PBC course and peripheral blood subpopulations.

Acknowledgements This work was supported by the Medical University of Lublin under Grant nos. DS 461/2016, DS 460/2017 and DS 360/2016.

Author contributions All authors contributed equally to this work and made substantial contributions to the study conception and design, and they contributed to the text of the paper.

Open Access This article is distributed under the terms of the Creative Commons Attribution 4.0 International License (http://creativeco mmons.org/licenses/by/4.0/), which permits unrestricted use, distribution, and reproduction in any medium, provided you give appropriate credit to the original author(s) and the source, provide a link to the Creative Commons license, and indicate if changes were made.

\section{References}

Berg PA (2011) The role of the innate immune recognition system in the pathogenesis of primary biliary cholangitis: a conceptual view. Liver Int 31:920-931

Bernuzzi F, Fenoglio D, Battaglia F et al (2010) Phenotypical and functional alterations of CD8 regulatory $\mathrm{T}$ cells in primary biliary cholangitis. J Autoimmun 35:176-180

Brand S (2009) Crohn's disease: Th1 Th17 or both? The change of a paradigm: new immunological and genetic insights implicate Th17 cells in the pathogenesis of Crohn's disease. Gut 58:1152-1167

Chen M, Chen G, Deng S et al (2012) IFN-beta induces the proliferation of CD $4+\mathrm{CD} 25+$ Foxp $3+$ regulatory T cells through upregulation of GITRL on dendritic cells in the treatment of multiple sclerosis. J Neuroimmunol 242:39-46

Chuang YH, Lian ZX, Yang GX et al (2008) Natural killer T cells exacerbate liver injury in a transforming growth factor beta receptor II dominant-negative mouse model of primary biliary cholangitis. Hepatology 47:571-580

Darmochwał-Kolarz D, Kłudka-Sternik M, Tabarkiewicz J et al (2012) The predominance of Th17 lymphocytes and decreased number and function of Treg cells in preeclampsia. J Reprod Immunol 93:75-81

Du W, Shen WY, Lee WH et al (2013) FoxP3(+) Treg expanded from patients with established diabetes reduce helios expression while retaining normal function compared to healthy individuals. PLoS One 8:e56209

Feng W, Li W, Liu W et al (2009) IL-17 induces myocardial fibrosis and enhances RANKL/OPG and MMP/TIMP signaling in isoproterenol-induced heart failure. Exp Mol Pathol 87:212-218

Fenoglio D, Bernuzzi F, Battaglia F et al (2012) Th17 and regulatory $\mathrm{T}$ lymphocytes in primary biliary cholangitis and systemic sclerosis as models of autoimmune fibrotic diseases. Autoimmun Rev 12:300-304

Feuerer M, Shen Y, Littman DR et al (2009) How punctual ablation of regulatory $\mathrm{T}$ cells unleashes an autoimmune lesion within the pancreatic islets. Immunity 31:654-664
Furuhashi T, Saito C, Torii K et al (2013) Photo(chemo)therapy reduces circulating Th17 cells and restores circulating regulatory $\mathrm{T}$ cells in psoriasis. PLoS One 8:e54895

Gasse P, Riteau N, Vacher R et al (2011) IL-1 and IL-23 mediate early IL-17A production in pulmonary inflammation leading to late fibrosis. PLoS One 6:e23185

Hamburg JP, Asmawidjaja PS, Davelaar N et al (2011) Th17 cells, but not Th1 cells, from patients with early rheumatoid arthritis are potent inducers of matrix metalloproteinases and proinflammatory cytokines upon synovial fibroblast interaction, including autocrine interleukin-17A production. Arthritis Rheum 63:73-83

Harada K, Shimoda S, Sato Y et al (2009) Periductal interleukin-17 production in association with biliary innate immunity contributes to the pathogenesis of cholangiopathy in primary biliary cholangitis. Clin Exp Immunol 157:261-270

Hot A, Miossec P (2011) Effects of interleukin (IL)-17A and IL-17F in human rheumatoid arthritis synoviocytes. Ann Rheum Dis 70:727-732

Huang W, Kachapati K, Adams D et al (2014) Murine autoimmune cholangitis requires two hits: cytotoxic KLRG1(+) CD8 effector cells and defective T regulatory cells. J Autoimmun 50:123-134

Huang Q, Chu S, Yin X et al (2016) Interleukin-17A-induced epithelial-mesenchymal transition of human intrahepatic biliary epithelial cells: implications for primary biliary cholangitis. Tohoku J Exp Med 240:269-275

Hus I, Starosławska E, Bojarska-Junak A et al (2011) CD3+/CD16+ CD56+ cell numbers in peripheral blood are correlated with higher tumor burden in patients with diffuse large B-cell lymphoma. Folia Histochem Cytobiol 49:183-187

Hus I, Bojarska-Junak A, Chocholska S et al (2013) Th17/IL-17A might play a protective role in chronic lymphocytic leukemia immunity. PLoS One 8:e78091

Hus I, Bojarska-Junak A, Kamińska M et al (2017) Imbalance in circulatory iNKT, Th17 and T regulatory cell frequencies in patients with B-cell non-Hodgkin's lymphoma. Oncol Lett 14:7957-7964

Jadidi-Niaragh F, Mirshafiey A (2011) Th17 cell, the new player of neuroinflammatory process in multiple sclerosis. Scand J Immunol 74:1-13

Ji X, Li J, Xu L et al (2013) IL4 and IL-17A provide a Th2/ Th17polarized inflammatory milieu in favor of TGF-beta1 to induce bronchial epithelial-mesenchymal transition (EMT). Int J Clin Exp Pathol 6:1481-1492

Kawata K, Tsuda M, Yang GX et al (2013) Identification of potential cytokine pathways for therapeutic intervention in murine primary biliary cholangitis. PLoS One 8:e74225

Kita H, Naidenko OV, Kronenberg M et al (2002) Quantitation and phenotypic analysis of natural killer T cells in primary biliary cholangitis using a human CD1d tetramer. Gastroenterology 123:1031-1043

Klatka M, Grywalska E, Partyka M et al (2014) Th17 and Treg cells in adolescents with Graves' disease. Impact of treatment with methimazole on these cell subsets. Autoimmunity 47:201-211

Klatka J, Grywalska E, Hymos A et al (2017) Subpopulations of natural killer-T-like cells before and after surgical treatment of laryngeal cancer. Cent Eur J Immunol 42:252-258

Lan RYZ, Salunga TL, Tsuneyama K et al (2009) Hepatic IL-17 responses in human and murine primary biliary cholangitis. $\mathbf{J}$ Autoimmun 32:43-51

Lanier LL (2008) Up on the tightrope: natural killer cell activation and inhibition. Nat Immunol 9:495-502

Lindor KD, Gershwin ME, Poupon R et al (2009) Primary biliary cirrhosis. AASLD Pract Guidel Hepatol 50:291-308 
Mackay IR (2007) Autoimmune diseases of the liver, autoimmune hepatitis and primary biliary cholangitis: unfinished business. Hepatol Res 37(Suppl 3):S357-S364

Mi S, Li Z, Yang HZ et al (2011) Blocking IL-17A promotes the resolution of pulmonary inflammation and fibrosis via TGF-beta1-dependent and independent mechanisms. J Immunol 187:3003-3014

Murdaca G, Colombo BM, Puppo F (2011) The role of Th17 lymphocytes in the autoimmune and chronic inflammatory diseases. Intern Emerg Med 6:487-495

Noubade R, Krementsov DN, Del Rio R et al (2011) Activation of p38 MAPK in CD4 T cells controls IL-17 production and autoimmune encephalomyelitis. Blood 118:3290-3300

Nowicka D, Grywalska E, Fitas E et al (2017) NK and NKT-like cells in patients with recurrent furunculosis. Arch Immunol Ther Exp. https://doi.org/10.1007/s00005-017-0500-8

Pasiarski M, Grywalska E, Kosmaczewska A et al (2015) Assessment of peripheral blood and bone marrow T, NK, NKT and dendritic cells in patients with multiple myeloma. Postepy Hig Med Dosw 69:1435-1442

Pesce B, Soto L, Sabugo F et al (2013) Effect of interleukin-6 receptor blockade on the balance between regulatory $\mathrm{T}$ cells and $\mathrm{T}$ helper type 17 cells in rheumatoid arthritis patients. Clin Exp Immunol 171:237-242

Romagnani S, Maggi E, Liotta F et al (2009) Properties and origin of human Th17 cells. Mol Immunol 47:3-7

Rong G, Zhou Y, Xiong Y et al (2009) Imbalance between T helper type 17 and $\mathrm{T}$ regulatory cells in patients with primary biliary cholangitis: the serum cytokine profile and peripheral cell population. Clin Exp Immunol 156:217-225

Selmi C, Lleo A, Pasini S et al (2009) Innate immunity and primary biliary cholangitis. Curr Mol Med 9:45-51

Shi T, Zhang T, Zhang L et al (2015) The distribution and the fibrotic role of elevated inflammatory th17 cells in patients with primary biliary cholangitis. Medicine 94:e1888
Shimoda S, Tsuneyama K, Kikuchi K et al (2012) The role of natural killer (NK) and NK T cells in the loss of tolerance in murine primary biliary cholangitis. Clin Exp Immunol 168:279-284

Singh TP, Schön MP, Wallbrecht K et al (2013) Involvement of IL-9 in Th17-associated inflammation and angiogenesis of psoriasis. PLoS One 8:e51752

van Herwijnen MJ, Wieten L, van der Zee R et al (2012) Regulatory T cells that recognize a ubiquitous stress-inducible self-antigen are long-lived suppressors of autoimmune arthritis. Proc Natl Acad Sci USA 109:14134-14139

Vargas-Lowy D, Kivisäkk P, Gandhi R et al (2012) Increased Th17 response to myelin peptides in pediatric MS. Clin Immunol 146:176-184

Vittal R, Fan L, Greenspan DS et al (2013) IL-17 induces type V collagen overexpression and EMT via TGF-beta-dependent pathways in obliterative bronchiolitis. Am J Physiol Lung Cell Mol Physiol 304:L401-L414

Wang YH, Yang W, Yang JB et al (2015) Systems biologic analysis of $\mathrm{T}$ regulatory cells genetic pathways in murine primary biliary cholangitis. J Autoimmun 59:26-37

Wilson MS, Madala SK, Ramalingam TR et al (2010) Bleomycin and IL-1beta-mediated pulmonary fibrosis is IL-17A dependent. J Exp Med 207:535-552

Wu SJ, Yang YH, Tsuneyama K et al (2011) Innate immunity and primary biliary cholangitis: activated invariant natural killer T cells exacerbate murine autoimmune cholangitis and fibrosis. Hepatology 53:915-925

Yang GX, Lian ZX, Chuang YH et al (2008) Adoptive transfer of CD8(+) T cells from transforming growth factor beta receptor type II (dominant negative form) induces autoimmune cholangitis in mice. Hepatology 47:1974-1982

Zhang B, Hu M, Zhang P et al (2013) BAFF promotes regulatory T-cell apoptosis and blocks cytokine production by activating B cells in primary biliary cholangitis. Braz J Med Biol Res 46:433-439 